\title{
25 Hydroxy-vitamin D status in patients with berardinelli-seip syndrome (congenital generalized lipodystrophy)
}

\author{
Lia Beatriz de Azevedo Souza Karbage, Ana Paula Dias Rangel Montenegro, Luciana Felipe Férrer Aragão, \\ Izabella Tamira Galdino Farias Vasconcelos, Virgínia Oliveira Fernandes, Annelise Barreto de Carvalho, \\ Clarisse Mourão Melo Ponte, Catarina Brasil D'Alva, Carla Soraya Costa Maia, Synara Cavalcante Lopes, \\ Marivaldo Loyola Aragão, Carla Antoniana Ferreira de Almeida Vieira*, Ana Paula Germano Lopes Cavalcante, \\ Renan Magalhães Montenegro Junior
}

From 20th Brazilian Diabetes Society Congress

Porto Alegre, Brazil. 11-18 November 2015

\section{Background}

Low status of 25-hydroxyvitamin D [25(OH)D] is defined as level $<30 \mathrm{ng} / \mathrm{mL}$. Studies indicate high prevalence of hypovitaminosis $\mathrm{D}$ at different ages in many regions of Brazil. It is associated with decreased insulin sensitivity and reduced pancreatic $\beta$-cell function. Berardinelli-Seip Syndrome (BS) is a rare congenital autosomal recessive disease due to mutations in 4 main genes (AGPAT2, BSCL2, CAV1 and PTRF). It presents lack of metabolically active fat, and ectopic adipose storage in liver and skeletal muscle, impaired metabolism of lipids and carbohydrates, insulin resistance, diabetes mellitus (DM) and dyslipidemia. We did not find in the literature descriptions about levels of $25(\mathrm{OH}) \mathrm{D}$ in groups of patients with BS.

\section{Objective}

To describe 25(OH)D blood levels and its correlation with insulin, glycosylated hemoglobin (A1c), HOMA-IR and hepatic steatosis in patients.

\section{Materials and methods}

Cross-sectional study conducted between 2013 and 2014. We evaluated 13 patients with BS followed at a University Hospital. Blood dosage of $25(\mathrm{OH}) \mathrm{D}$, insulin, A1c, HOMA-IR, abdominal ultrasound and genetic study was made. Associations were tested by Spearman's rank correlaction coefficient.

* Correspondence: carlaantoniana@yahoo.com.br Universidade Federal do Ceará, Fortaleza, Brazil

\section{Results}

The results were expressed as median, 25th percentile and 75th percentile for 25(OH)D levels, mean and standard deviation for other laboratory tests, and absolute frequency for the other variables. The median of 25 $(\mathrm{OH}) \mathrm{D}$ was $36.3(26.3-40.5) \mathrm{ng} / \mathrm{mL}$. Nine patients presented normal levels of $25(\mathrm{OH}) \mathrm{D}$, with median of 40.5 (36.3-42.1) ng/mL, 2 presented insufficiency $(26 \mathrm{ng} / \mathrm{mL})$ and 2 presented deficiency $(18.2 \mathrm{ng} / \mathrm{mL})$. Among other variables, 6 patients had DM, 12 hepatomegaly and 4 hepatic steatosis. All patients had severe low leptin levels $(1.2 \pm 0.3 \mathrm{ng} / \mathrm{mL})$. Four patients showed mutation on AGPAT2 gene, and 6 on BSCL2. The genetic study of 3 patients is in progress. The correlation coefficients between 25(OH)D levels and insulin, A1c, HOMA-IR, DM, and hepatic steatosis were not significant.

\section{Conclusion}

In this study there was an unexpected predominance of normal levels of $25(\mathrm{OH}) \mathrm{D}$ in patients with $\mathrm{BS}$, which is not an usual finding in Brazilian population nowadays. Some authors hypothesize that high leptin levels impairs the synthesis of $25(\mathrm{OH}) \mathrm{D}$ in obese. It may suggest a possible role of leptin deficiency in the $25(\mathrm{OH}) \mathrm{D}$ sufficiency in BS. Another hypothesis are that excess of subcutaneous fat would sequester vitamin $\mathrm{D}$ and that hepatic injury would result in low $25(\mathrm{OH}) \mathrm{D}$ synthesis. 
doi:10.1186/1758-5996-7-S1-A108

Cite this article as: de Azevedo Souza Karbage et al:: 25 Hydroxy-vitamin

D status in patients with berardinelli-seip syndrome (congenital

generalized lipodystrophy). Diabetology \& Metabolic Syndrome 20157

(Suppl 1):A108

Submit your next manuscript to BioMed Central and take full advantage of:

- Convenient online submission

- Thorough peer review

- No space constraints or color figure charges

- Immediate publication on acceptance

- Inclusion in PubMed, CAS, Scopus and Google Scholar

- Research which is freely available for redistribution

Submit your manuscript at 